\title{
Cultural Nationalism or Escapist Idealism: Okot P'bitek's Song of Lawino and Song of Ocol
}

Dr. Victor Onyango Ouno, PhD

Maseno University, Kenya.

DOI: $10.46382 / M J B A S .2020 .4308$

Article Received: 27 June 2020

This article seeks to demonstrate that cultural nationalism has been a significant ideological force in African literary writings in general and poetry in particular. It endorses a distinctive communitarian vision of the nation and has repeatedly been espoused by many a literary academic as a remarkable effort towards the re-establishment of coherence and integrity in African traditional life and institutions. While recognising the beauty of traditional life, this approach turns a blind eye to the endemic challenges that these nations are grappling with. Taking Okot's Song of Lawino and Song of Ocol as the literary points of reference, I have delineated the character of cultural nationalism, the leadership role of the colonised intellectual, and its recurring emergence in alternation with escapist idealism. Using Fanonian theory, I have argued that rather than idolise the past in what may be largely interpreted as idealist escapism, Okot's intent in the two poems selected for this study is to offer a truthful, accurate and objective representation of the real African world. He divorces his poems, Sengorian and Negritudist as they may seem, from rigid cultural historicism and espouses the marginalised perspective that Africa's culture is a product of shared heritage and the desire for liberation should not blind us to the dynamism of our culture and the reality that neocolonialism has ushered in a new political culture that should worry us more than the coloniser's. It is not enough for us to look only backwards in our quest for cultural revolution.

Keywords: Cultural nationalism, Idealism, Escapism, Colonised intellectual, Fanonianism.

This article examines Okot p'Bitek's poems, Song of Lawino and Song of Ocol, as case studies in perspectives on nationalism and identity in the contemporary African society. The assessment in this article is based on Fanonian theory, which falls within the broader context of postcolonial literary criticism and analysis and provides a historical context to cultural nationalism. Okot's legacy has hinged on his participation in the reification of Africa's cultural pride, but popular memory of that event has subsumed the diverse views of its similar advocates into a rigid national narrative that overlooks the dynamism of societies. In contrast, this article argues that poetry in Africa and the African mode in poetry that it posits present a broader and more inclusive ideal. Okot defines the African nation based on shared history and heritage, but acknowledges the consequences of that history, such as the presence of two linguistic traditions, African and English. He expresses, in what appears to be a quest for cultural revolution, the need to look forward and not only backwards for unity. This view of Okot p'Bitek's poetry has long been marginalised, when mentioned at all, in both history and literary criticism. Yet this is a progressive cultural dimension that need to be explored.

Rather than idolise the past in what may be largely interpreted as idealist escapism, Okot's intent in the two poems selected for this study is to offer a truthful, accurate and objective representation of the real African world. To achieve this aim, Okot utilises a number of literary strategies: the use of descriptive and evocative detail; avoidance of what was fantastical, imaginary, and mythical; inclusion of characters and incidents from all social strata, dealing not merely with rulers and nobility; focusing on the present and choosing topics from contemporary life while expressing longing for some idealised past; emphasising the social rather than the individual (or seeing the individual as a social being); refraining from the use of standardised, elevated language, in favour of more colloquial idioms and everyday speech, as well as directness and simplicity of expression. All of these stylistic 
strategies are triggered by giving prominence to direct observation, factuality, experience, and induction (arriving at general truths only on the basis of repeated experience). In adopting the strategies listed above, Okot's cultural vision endorses a broad and multipronged reaction against the idealisation, historical retrospection, and the imaginary worlds seen as characterising Romanticism.

African cultural nationalists sought to re-establish coherence and integrity in African life through programmes of cultural retrieval. The efforts in Literature resulted in the works, especially poetry categorised as those of cultural nationalism which debunked Western European culture and extolled Africa's traditions. The flourishing of Negritude poetry can be attributed these programmes. By focusing on the presentation of pre-colonial or colonial African societies, as in Okot's Song of Lawino, these poems have drawn attention to the wholesome dignity of African traditional life and institutions.

Culture is arguably not an easy term to explain. Two American anthropologists, Kroeber and Kluckhohn, took a critical relook at multiple definitions of culture. The duo documented a list of one-sixty-four different definitions. Apte's summary of the difficulty in defining the term is as follows: 'Despite a century of efforts to define culture adequately, there was in the early 1990s no agreement among anthropologists regarding its nature.' This does not mean that a working definition of the term cannot be arrived at. For the purpose of the discussions in paper, Kroeber and Kluckholm will suffice. The two argue that it (culture) 'consists of patterns, explicit and implicit, of and for behaviour acquired and transmitted by symbols, constituting the distinctive achievements of human groups, including their embodiment in artifacts; the essential core of culture consists of traditional (i.e. historically derived and selected) ideas and especially their attached values; culture systems may, on the one hand, be considered as products of action, on the other, as conditional elements of future action' (Kroeber and Kluckhohn qtd. in Adler 14).

In pre-literate African societies, culture was transmitted through oral traditions. Oral literary materials carried coded messages about communities' cultures. These oral materials were handed down to generations by word of mouth. Today, the advent of writing and other technologies has drastically changed the modes of cultural transmission in African societies. Parents and adults are no longer the custodians of cultural ethos. The world has become a global village and cultural boundaries are increasingly becoming indistinct. Cultural transmission may vary from one society to the other; however, in a fast-globalising world, disparities in modes of transmission fade by day. Wilberforce succinctly captures cultural dynamics when he says:

Let us endeavour to strike our roots into their soil by the gradual introduction and establishment of our own principles and opinions: our laws, institutions and manners; above all, as the source of every other improvement, of our religion and consequently of our morals. (Wilberforce, qtd. in Kapo 33).

Literature played an important role because cultural nationalists sought to use the power of a shared heritage and history to transcend divisions, uniting all "in the task of constructing an integrated, distinctive and autonomous community" that could bring the nation from "degeneration" to "regeneration" (Hutchinson, 34; Mays, 7; McKenna, 401; Foster, 454-6). George Russell (AE) stated that "a nation exists primarily because of its own 
imagination of itself", but Africa had lost that unity of imagination under the influence of colonialism and its empire. Only when the people of the land all believed in belonging to a greater national community (an "imagined community", to use Benedict Anderson's concept), sharing an identity and heritage, could the nation truly exist. Through the new body of writing, the leaders of the Negritude movement sought to create an aesthetic in order to regenerate the national spirit culturally. Debates centred on how to define and delineate Africa's cultural distinctiveness and the beliefs of prominent figures in the movement diverged as it evolved, threatening this autonomy, but nonetheless the idea remained a potent force. Okot's poetry seems to suggest that this cultural revival has given to some of us a new arrogance": it developed the "heart" of the nation and created a sense of pride among the people.

Although the literature on cultural nationalism is vast, little attention has been paid to role of cultural nationalism in the formation of nations in the twentieth century. Analysts have chosen to concentrate on the apparently more significant political nationalist movements, their mass mobilising strategies against the state, and their attempts to build a representative citizen-state. It is true that cultural nationalism is usually little more than a small-scale coterie of historical scholars and artists, concerned to revitalise the community by invoking memories of the nation as ancient and unique civilisation. But periodically, it has expanded into a major ideological movement that, challenging both established political nationalist movements and the existing state, has sought to regenerate the nation on communitarianism. Geertz observes:

[T] he concept of culture has its impact on the concept of man...[w] hen seen as a set of symbolic devices for controlling behaviour, extrasomatic sources of information,... [which provide] the link between what men are intrinsically capable of becoming and what they actually, one by one, in fact become. Becoming human is becoming individual and we become individuals under the guidance of cultural patterns historically created systems of meaning in terms of which we give form, order, point and direction to our lives. (Geertz, 'Impact'

Malara Ogundipe-Leslie claims, “...Song of Lawino is one of the most critically neglected works in African literature" (7). She further argues that despite the lyricism and imagery which brought this work to the attention of the world, Song of Lawino is essentially untrue, "the mission-educated man's vision of Africa” (7). It is, however, precisely in its "untruth" that Okot p'Bitek's representation of Africa in Song of Lawino and Song of Ocol is truest. One discovers that Lawino has no voice of her own, being Ocol's projection of his own repressed oedipal fixation, against which he reacts intensely both in the fictionalised Lawino's presentation of him and in his own song. This distorted view of the mission-educated man, Ocol, shows clearly the dilemma of modern Africa, for only in the distortion can the complex nature of the dilemma be discovered. In the ensuing Fanonian analysis, then, Lawino and Ocol emerge as symbols of cultural binaries that define the contemporary African society. Just below the surface of matrimonial discord lurks this cultural source of conflict and self-hatred. The overall thrust of Song of Lawino is to decry Ocol's rejection of Lawino. But, while claiming to be Ocol's legitimate wife, Lawino presents herself through images symbolic of the womb and motherhood and refers, further, to Ocol's being like a child, thus asserting the collectivity, which is the assertive voice of mother Africa. 
Furthermore, Lawino warns Ocol about the castrating European educational system, identifying, thus, Europe as impediment to Africa's self-determination through cultural assertiveness. Ocol's new-found obsession with Clementine (Tina), a modern woman, demonstrates his desire to depart from a traditional cultural lineage that no longer seems beneficial to him. The new Africa, it would appear, is defined by her European founders, rendering claims of its cultural distinctiveness untenable.

The primary relationship of the two poems thus found to be misrepresented by the characters, the authenticity of the characters themselves comes into question, particularly the authenticity of Lawino as an oral villager as she so assertively demands the reinstatement of the misrepresented relationship. Ogundipe-Leslie claims Lawino to be, in fact, an "impossible and unlikely image of the rural woman" (7). And indeed, while representing herself as an oral villager and an exemplar of Acholi values, Lawino is actually a literate violator of the values she claims to uphold. Lawino advocates for cultural nationalism, yet her actions, in a number of cases, advertently or inadvertently, negate her proclamations. Ogundipe-Leslie's position is a critical entry point in discussions revolving around cultural nationalism, realism and escapist idealism. For, if one applies Walter Ong's elements of orality to Lawino's song, one finds that, despite heavy borrowing of techniques commonly used in Acholi orature, Lawino "sings" in a style and with a consciousness which are necessarily literate. Her consciousness of the West and her husband's mannerisms, her image-laden defense of Acoli culture, her surgical description of Clementine's demeanor and her overall cultural impressions speak of a refined academic.

Yet it is this 'honest deception,' to borrow Leech and Short's expression, that makes Song of Lawino interesting and indeed many literary works thrive on sincere lies. Okot seems to suggest, and admittedly accurately so, that African civilisation has always been associated with backwardness and ignorance. Those who profess it, presumably the pre-literate, are perceived to unlearned, unintelligent and uneducated. They are, in this light, incapable of sustaining intellectual or academically demanding debates. Okot's choice of a village woman here is deliberately significant. He is able to relay his message forcefully without appearing to be doing so. Lawino is the antithesis of this misleading thesis. She is largely emotional, sentimental as it were, as expected in oral poetry; but her sentiments are not devoid of intellectualism. She dissects the Western civilisation with the finesse of a refined academic. She may exhibit tactlessness in certain instances, but her focus is largely on the ultimate price. By using Lawino, a presumably illiterate woman; Okot disabuses of the notion that civilisation is an exclusively European affair. And to this extent, his depiction of cultural nationalism is reasonable as it is justifiable.

Okot p'Bitek's portrayal of cultural nationalism is replete with controversies and inconsistencies. Lawino, the self-proclaimed advocate of African culture, fails to follow the basic rule for the Acholi woman: to obey and to respect her husband. It is she who misrepresents Black pride and cultural nationalism because she occasionally admits to having no qualms with Westernisation. In doing so, she misrepresents her own identity as well and one is bound to accuse her of some inauthenticity. Critics tend to agree that she, rather than Ocol, is the insecure, unhappy, or psychologically afflicted one. And while Ogundipe-Leslie asserts that, "The figure of Lawino is a displacement from the mind of a male, Westernized writer ..." (7), indicating authorial misrepresentation at the root of the "impossible and unlikely image of the rural woman" (7), p'Bitek has not misrepresented but has, rather, 
accurately represented the "complexities" of his character Lawino. Lawino is fixated in the crude stage of cultural development, her true desire being for an idealised motherland. Yet, unable to accept this utopianism is fast fading and no longer practical in the modern age, she represses all knowledge of it. As it does not disappear, however, she projects it onto her fictionalised image of Africa, her romanticisation of this image blinds her to realities of modern-day realities. She accommodates and dams up her repressive tendencies of the desire by projecting her husband, Ocol as a cultural recluse.

Thus Song of Lawino is Lawino's masked expression of her own repressed desire. Her reaction to the anchorite is her expression of the inability of continent to retrieve her ideal past. And similarly, Song of Ocol is Ocol's open criticism of Lawino's masked, repressed desire, yet Ocol himself is not without faults. It may be justifiable to contend that there is no "true" voice given us--either in Song of Lawino or in Song of Ocol. Both voices are, indeed, as Ogundipe-Leslie claims, the distorted view of a "mission-educated" man: Ocol. This truth, then, is an examination of the "complexity" of building a future for an Africa with an (as yet unresolved) "complex" past. The first textual hint of Lawino's lament about an unresolved past comes in the very first segment of Section 1 of Song of Lawino:

Husband, now you despise me

Now you treat me with spite

You say you no longer want me

Because I am like the things left behind

In the deserted homestead.

Stop treating me like salt-less ash

Become barren of insults and stupidity;

Who has ever uprooted the Pumpkin? (37-38)

Here, Lawino compares Ocol's now despising her with the uprooting of the pumpkin. From a Freudian perspective, the pumpkin in all its voluptuous rotundity is a symbol of the fruitful womb, of motherhood. The poem's overall thrust, furthermore, is to decry Ocol's rejection of mother Africa, his cultural heritage. Thus one sees this injunction against uprooting the pumpkin as against Ocol's destruction of the womb which gave him life, against destroying Lawino. In Section 2 ("The Woman With Whom I share My Husband"), Lawino claims, "Ocol rejects the old type/ ... /Ocol is no longer in love with the old type," going on to describe Ocol's new wife (Lawino 39-40). Yet what she seems to describe here is her husband's - turning away from his previous sexual urges and finding an acceptable, sublimated, reproductive outlet for his sexuality. The "old type" can be seen as equivalent, in this context, to the first love and by extension, Ocol's first cultural intimacy with mother Africa. Yet here Lawino equates herself with the "old type." She is the first "wife," the first love of Ocol. She further describes her erstwhile relationship with Ocol: "But only recently/We would sit close together, touching each other! Only recently he promised/That he trusted me completely/ I used to admire him speaking in English" (Lawino 39). It 
takes only the hint of the possibility of the relationship being that of mother Africa and her cultural apostates. Westernisation has seen rapid and significant changes in cultural consciousness. Staunch cultural adherents have quickly, and unexpectedly so, metamorphosed into cultural recreants. "Only recently" is repetitively used to emphasise the suddenness of cultural transition in Africa. Ocol no longer prides in his wife and her cultural inclinations. Thus Lawino again reveals herself as the face of Africa in undefiled state. Though she recognises that things have changed, she is still holding on to the past. Her cultural nostalgia is reinforced in the following:

I do not block my husband's path

From his new wife.

If he likes, let him build for her

An iron roofed house on the hill!

I do not complain,

My grass thatched house is enough for me. (Lawino 44)

One sees here in Lawino a classical case of selflessness, which is representative of the cultural ideal that Africa signified. The artificial glamour of the West as symbolised by the "iron roof" does not seem to bother her. She is contented with her grass-thatched house. She is the mother who must accept less than the best from her son, because he has established his own household. And she is not about to let him forget her sacrifice. But her sacrifice is one which began much earlier. "When Ocol was wooing me/" she says, "My breasts were erect" (Lawino 50). Here Lawino is referring to African culture in its unadulterated form. Before the intrusion of foreign value systems and the subsequent adulteration, African culture in its pristine form was alluring, attractive and irresistible. It was idyllic. But through its contact with the West, it has lost its virginity, its irresistible allure. This interpretation is further supported in that she compares Ocol's former longing for her with a child's longing for his mother:

The son of the Bull wept

For me with tears,

Like a hungry child

Whose mother has stayed long

In the simsim field! (Lawino 51)

Thus in conjunction with an insinuation as to the true nature of Lawino and Ocol's relationship, one finds Lawino exposing, on the one hand, the very thing that, on the other hand, her posing as wife seeks to conceal: her desire for Ocol. The seventh section is a furtherance of the child narrative. The supercilious Lawino shows her husband Ocol as a child; indeed, she describes him as a "a small boy" who continues to act as a child, although he is now an adult:

My husband runs from place to place

Like a small boy,

He rushes without dignity. (Lawino 71) 
This perpetuated childhood can, however, be interpreted as a simplified representation of Ocol's fixation in an early stage of cultural development, which blinds Africans to inadequacies of their own cultures. And as a result of this fixation, the cultural nationalist is unable to progress into a normal, balanced individual with the capacity to discern. It is important to note that it is Lawino rather than Ocol seems unwilling to grow. Lawino says of Ocol, "He says I make his bedsheets dirty" (Lawino 56). Though this filth is presented as physical, the overall moral thrust of Lawino's argument leads one to view any filth in moral terms. Yet she does not express a firm repudiation of her existence. Lawino, however, continues to obfuscate the true nature of her relationship with Ocol:

Come, brother,

Come into my mother's house!

Pause a bit by the door,

Let me show you

My mother's house. (Lawino 62)

By addressing Ocol as her "brother," she presents him as her agemate. Yet the ambiguity of the invitation to enter her "mother's house" is overwhelming. While, literally interpreted, the house is the house belonging to her mother, it becomes, the epicentre of cultural nationalism. This invitation into the mother's house appears then as an attempt to revive lost cultural intimacy. For, further, in metaphoric terms, the house is a womb image; thus the invitation to enter is an invitation to resuscitate Ocol's connection to Africa and its cultural heritage. H. O. Anyumba mentions "a certain vicarious relationship between Ocol and Lawino which contradicts an overt polarity." He further claims that, "This relationship is extended to include mother and mother-in-law, clansmen, the ancestral shrine, which are the various connections linking the two as individuals and also to society at large" (Anyumba 32). Yet one can see in these disparate elements something much more than common joining functions for the husband and wife, Ocol and Lawino. These elements compose the psychological womb from which Ocol sprang and are thus true extensions of his lineage. This extension justifies the interpretation that Lawino represents Africa's culture and Ocol is an apostate. So when Lawino says, "He cares little/About his relatives either" (Lawino 95), she is not complaining more specifically about his neglecting and rejecting her, but more about his rebelling against his people and what defines his clan, the Black people and specifically Africa. This interpretation is supported by Lawino herself as she continues: Of his own mother, Ocol says She smokes some nauseating tobacco And spits all over the place And she keeps bed bugs In her loin cloth (Lawino 95)

Images of sexuality, particularly castrations, pervades the cultural persuasions posited in part ten and the subsequent parts of Lawino's song. Lawino's appeal to Ocol's masculinity goes beyond narrow confines of gender-based insinuations. Okot, like Wole Soyinka, appears to be appealing to a defeminised, asexual dimensions of manhood. Ocol is unable to project the spiritual fortitude of "the man" in Armah's The Beautyful Ones Are Not Yet Born because his exposure to the West has killed the man in him and indeed "all young men" whose testicles have been "smashed with large books" (Lawino 120). Thus, Okot, like Soyinka, suggests: "The man dies in all of us who keep silent in the face of [cultural] tyranny" (The Man Died). Lawino, naturally enough, objects to Ocol's 
generally unflattering portrayal of her. Yet particularly objectionable is his vilification of her sexuality; the loins from which he sprang and to which Lawino calls him to return must not be the home of pests and disease! Lawino objects further:

You cannot abuse your mother!

Because it was that woman

Who hewed you out of the rock

And moulded your head and body. (Lawino 102)

In so saying, she does, in effect, the very thing she described in the immediately preceding passage: she has lifted her breast to Ocol and asked, "Did you suck this?" (Lawino 102). In so doing she condemns him for rejecting her. It is in this act above all others that she shows her true relationship to Ocol. Ironically, Lawino uses this display of the motherly breast primarily as leverage to call Ocol back to their "marriage" bed and, by extension, original cultural intimacy. To ease generally the interpretive strategy of equating a son and a husband, one should note that Lawino asks, perhaps unwittingly, "What is so sweet in your husband?/What so bitter in other people's sons?" (Lawino 101). This parallel structure appears at first to be merely a faulty comparison of categories which are not mutually exclusive. A husband is, after all, the son of "other people." Yet, if the comparison is to be accepted as valid, the husband she refers to must needs be the son of the woman whose "husband" she has called him. Thus through parallel structure, Lawino reiterates her desire for the natural intimacy of a "husband," less disturbed by the West. Lawino, however, could hardly be more explicit in her acceptance of Africa's naturalness, especially when she speaks of death: Mother Death She says to her little ones Come! (Lawino 105) And the little ones follow her because what she offers is appealing. She is, thus, longing for unquestionable cultural loyalty, which is only attainable in childhood. Yet it is this very childhood innocence that she abhors. Thus Lawino seems to claim that Ocol can find nothing more appealing than her - in fact she portrays herself as being as compelling as death. But perhaps the most significant expression of Lawino's mother relationship to Ocol is her threatening and warning Ocol of the danger of castration, a natural role of the mother. She warns him of the result of angering his mother:

Your vitality will go,

You will behave

As if you were a half-wit,

\section{Your Manhood will disappear}

And like a castrated bullock

Women will be perfectly safe with you! (Lawino 102)

Then she speaks as though this castration were already an accomplished fact. She speaks of the "death of the homestead/of my husband" (Lawino 113). And in the past tense she speaks of a time when "He [Ocol] had not yet become a woman" (Lawino 115). The castrator, who apparently is not expressed in human terms, has already 
accomplished the dreaded punishment and Ocol is no longer free. Lawino presents the Eurocentric colonial education system as the castrator. "Ocol," she says, "has lost his head/ In the forest of books" (Lawino 116). Through the use here of the double entendre "head," Lawino is able to link Ocol's mental state with his loss of virility, his castration. And both the mental and physical emasculations take place, according to Lawino, in the library, an adjunct to the colonial schools and the repository of Western knowledge and culture. She proceeds through the use of an implied metaphor, comparing testicles to eyeballs, to present the frightful loss: He says The ways of the people Are black Because his eyeballs have exploded. (Lawino 116) “... the boiling darkness Bursts your eyeballs. (Lawino 117) In Lawino's folk wisdom, reading has blinded her husband; he no longer sees black for who they are but myopically as people whose ways are 'black.' The twelfth section of the song, "My Husband's House is a Dark Forest of Books" is largely Lawino's dismissal of Western sources of knowledge.

Western culture, it appears, does not have life. Any contact with the West amounts to infertility as one is castrated. The library is portrayed as a weaponised space for cultural erosion. Lawino elaborates on the place where the loss occurred, speaking of "the blindness that you got in the library" (Lawino 118), the forest of books. In reference to the Eurocentric book learning obtained in this library, she seems to be wondering why Ocol imitates the Whites when Africans have their own manner of thinking, their own institutions, their education system. Yet Lawino herself knows that cultural autonomy is no longer truly an option for those who have received an education in the colonial school system. In fact, she claims, "There is not one single true son left" (Lawino 117): "[f]or all our young men [w]ere finished in the forest, [t]heir manhood was finished [i]n the class-rooms, [t]heir testicles [w]ere smashed [w]ith large books!" (Lawino 117) This view of education as a destructive force in Africa is supported by La Magna who avers that Western "education simply castrates the African intelligentzia [sic] from their own tribe and customs and produces superficial and awkward imitators" (71). It is a view also reinforced, though in slightly severe terms, by Terrisse: "The school necessarily is in the position of transforming the child and developing new knowledge in him. As a consequence, the school makes him different from his environment" (291). Despite these references to the educational destruction, castration, of the young men of Acholiland, and specifically of Ocol, however, Lawino offers a belated escape from this fate via a return to the village ways:

\section{Beg forgiveness from them}

And ask them to give you

A new spear

A new spear with a sharp and hard point.

A spear that will crack the rock.

Ask for a spear that you will trust

One that does not bend easily

Like the earth-worm.

Ask them [your ancestors] to restore your manhood! 
For I am sick

Of sharing a bed with a woman! (Lawino 122)

Ironically, in all these depictions and threats of castration, one sees Lawino once again using her natural and acceptable actions whose intentions are to restore normal marital sexuality between her and Ocol. She is evidently tired of Clementina's intrusion into their lives. The modern, westernised "second-wife" whom Lawino ridicules as looking like "a guinea fowl" (Lawino 37) and whom she despises as having "a fruitless womb" - perhaps because of abortions (Lawino 39) has blinded Ocol to her very existence. The castrating Eurocentric colonial education acquires a metaphorical meaning here. Castration speaks of inability to resist the counter-productive effects of a foreign value system. It goes beyond the physical dysfunctionality and suggests a lack of mental power to fight against cultural erosion as perpetuated by westernisation. Ocol's physical inability to rise to the occasion is indicative of his incapacity to acknowledge the beauty of African culture as encapsulated in the body of Lawino.

Perhaps, it is the eleventh part of this song that acutely captures the contrast between cultural nationalism and idealist escapism. Okot titles this section "Buffaloes of Poverty Knock the People Down." This section represents a neocolonial African set-up. A number of political parties have sprung up. The clamour for liberation from neo-colonisers has gained momentum. But Okot does not shy away from revealing the inherent contradictions in these political campaigns. Lawino is still holding on to the past and longs for a recreation of the perfect past. Ocol's political activities stand in sharp contrast to Africa's traditions and history. Lawino likens Ocol's political actions to past, an indication that she is still longing for a return to pre-colonial history. Ocol, for instance, "roams the country like a wild goat" and wakes up before dawn like someone who "is going to hoe the new cotton field" (Lawino 106).

By and large, Lawino's sentiments reflect Fanon's observations in "On National Culture" in The Wretched of the Earth. Fanon, in this essay, sets out to define how a national culture can emerge among the formerly and neo-colonised nations of Africa. Rather than depending on an orientalised, fetishised understanding of pre-colonial history as Lawino seems to be doing, Fanon argues a national culture should be built on the material resistance of a people against colonial domination. In this essay, Fanon makes reference to what he calls the "colonised intellectual," which is a befitting title for Lawino's husband Ocol. For Fanon, colonisers attempt to write the precolonial history of a colonised people as one of "barbarism, degradation, and bestiality" in order to justify the supremacy of Western civilisation. To upset the supremacy of the colonial society, writes Fanon, the colonised intellectual feels the need to return to their so-called "barbaric" culture, to prove its existence and its value in relation to the West.

Fanon suggests colonised intellectuals often fall into the trap of trying to prove the existence of a common African or "Negro" culture. This is a dead end, according to Fanon, because it was originally the colonists who essentialised all peoples in Africa as "Negro," without considering distinct national cultures and histories. This points to what Fanon sees as one of the limitations of the Négritude movement. In articulating a continental identity, based on the colonial category of the "Negro," Fanon argues, "the men who set out to embody it realised 
that every culture is first and foremost national." An attempt among colonised intellectuals to "return" to the nation's precolonial culture is then ultimately an unfruitful pursuit, according to Fanon. Rather than a culture, the intellectual emphasises traditions, costumes, and clichés, which romanticise history in a similar way as the colonist would. The desire to reconsider the nation's pre-colonial history, even if it results in orientalised clichés, still marks an important turn according to Fanon, since by rejecting the normalised eurocentrism of colonial thought, these intellectuals provide a "radical condemnation" of the larger colonial enterprise. Fanon contends that this radical condemnation attains its full meaning when we regard the "final aim of colonisation was to convince the indigenous population that it would save them from darkness." A tenacious refusal by traditional African diehards, escapist idealists like Lawino, so to say, to admonish national traditions in the face of colonial rule, avers Fanon, is a demonstration of nationhood, but one that holds on to a fixed idea of the nation as something of the past, a corpse. Lawino still believes, for instance, that a married woman has to submit to communal wishes so that when her husband dies, she, her children and her husband's property are automatically inherited by her husband's brother and that fatness is a sign of opulence.

The thirteenth part of the song, "Let Them Prepare the Malakwang Dish," thus unveils a number of inconsistencies. Lawino's defiance is even louder here; she dismisses Western values, rubbishing the church and Christian values, discrediting modern literature and sources of knowledge such as books, magazines, newspapers, radio and television. Instead she prescribes traditional food and herbs and recognises their redemptive power. She suggests that Ocol's resurrection, redemption from the captivity of western civilisation, is dependent on his acknowledgement of the power of local medicinal solutions. The insults hurled at her are directed at the African ancestry in its entirety and Ocol's parents in particular. To redeem himself, he has to seek forgiveness from his parents.

What is particularly worth noting in this section is that Lawino recognises Tina as Ocol's second wife. She reminds Ocol of her position as the first wife. Whereas she asks her husband to buy Tina such material possessions as clothes, beads, perfume, necklaces, shoes and earrings; she appears to have toned down her repulsion towards them. For instance, she does not "ask for money, [a]though she has need of it" (Lawino 122). She is obviously attracted to Ocol's new lifestyle. The traditional foods, largely vegetables, which she prescribes as the remedies for Ocol's lack of strength, ill-health and general inability to make informed decisions, are no longer good for her in the long run. She "can only live on green vegetables [for] a while" (Lawino 123). Once Ocol recovers, she expects her share of lavishness from her husband. Her declaration of undying love for Ocol is pegged on Ocol's removal of "the road block [from her] path." She is more than willing to dance before her husband to "show [him] the wealth in [his] house" (Lawino 123).

Song of Ocol is a rebuttal of the charges levelled against Ocol in Song of Lawino. It is divided into nine parts, in what may be read as a series of stinging diatribes. In first part of this rebuttal, Ocol, seemingly unwillingly to tolerate Lawino, asks her to shut up, pack her things and leave the house. It is obviously an open display of arrogance. In the second stanza, Ocol gives us the very first clearest hint, unlike in Song of Lawino where she admits to being a little jealous, a feeling that, she justifies, catches everyone unawares, that Lawino's cultural 
loyalty may be questionable. Ocol had actually bought her clothes, beads and necklaces. Here, it would appear Lawino had failed the Abiku test.

In the subsequent stanzas, Ocol launches an attack against cultural nationalism. "Song of the woman," a celebration of African cultural values, no longer has a place in the modern society. To hold on to them amounts to nothing:

Song of the woman

Is the confused noise

Made by the ram

After the butcher's knife

Has sunk past

The wind pipe,

Red paint spraying

On the grasses;

It is a song all alone

A solo fragment

With no chorus

No accompaniment

A strange melody

Impossible to orchestrate; (124)

In Song of Ocol he first alludes to Lawino's desires, using the metaphor of the pumpkin: "I see a large Pumpkin/Rotting" (124). This rotting which he claims to see in the fruitful womb, when taken as having a human referent, is necessarily a moral decay arising from cultural erosion. Thus Ocol here demonstrates the awareness that a return to the cultural past is untenable. Yet he is far from absolute in his stance against Lawino's impractical desires: We will smash The taboos One by one (Lawino 126). Among these taboos which Ocol would smash are retrogressive cultural practices that keep watering down the visions of Africa's freedom fighters. Thus if he succeeds in his eradication of the taboo system, he will be freeing himself from idolisation of Africa's past. Once again, however, he condemns escapist idealism as cowardly and foolish:

Out of my way

You cowardly fool

Creep back and hide

In your mother's womb. (148) 
There are challenges in modern African societies that require practical solutions. Sexual immorality in the form of prostitution has led to the spread of sexually transmitted diseases such as syphilis, the rate of unemployment in Africa is alarming, gender inequality or subjugation of women, cattle rustling, neocolonialism or modern slavery, deceit and servitude are some of ills bedeviling African nations. For only in its primal form can African's culturalism idealism be regained. Ocol finds such action cowardly because it entails a desire to escape the outer world and foolish because, even once attained through revival, in a fast globalising world, Africa's cultural virginity cannot be sustained. Besides, it is no longer practical to hold on to traditions, yet the world is modernising by day. There are certain aspects of African cultural values may be idealistic, worthy of praise and pride, yet is wrong to presume that westernisation is wholly evil. Correspondingly; African traditions, practices, beliefs and customs are not wholly ideal. Ocol points out specific aspects of African culture that are reproachable: the war dances, the poisoned arrows and the Maasai culture permits adultery (one is permitted to sleep with another's wife by merely planting a spear at their door). Overreliance on rudimentary skills coupled with unrelenting attachment to traditional norms blinded Africans to the reality of the day; they busied themselves "chasing wild animals, thoughtless and carefree" (142). All this while, it did not occur to them that a struggle for liberation from colonial dominion was necessary. It is this escapist mentality that still informs the lacklustre attitude of Africans. They do not participate meaningfully to restore Africa's lost glory. If this primal desire is the way of the fool and if the pumpkin, with its attachment in the Acholi mind to the traditional homestead, is the symbol of the desired culture, then Ocol can justifiably claim to have achieved the resolution of escapist idealism:

\section{And let the people sing and dance}

And celebrate the passing of The Old Homestead! (147)

Yet even with these clues to Ocol's rejection, if only tentative, of Lawino's appeal to his emotional attachment to his country, his position on the traditional structure of African civilisation appears clearest in his reference to Europe. He states: We spent years In detention Suffering without bitterness And planning for the revolution (139). In Fanonian terms, every revolution is a rejection of and an attempt to decimate colonial dominion. Here it is no different. Lawino has identified the castrator as the eurocentric educational system or, in more general terms, Europe. And Ocol's revolution is aimed at killing, eliminating, emasculating, or in some way rendering impotent the European coloniser. Yet also in accordance with Fanonian theory, the revolution successfully completed, Ocol wants, needs, to make a god of the emasculated and silenced voices of African patriarchs:

We will erect monuments

To the founders

Of modern Africa:

Leopold II of Belgium Bismark.... (151)

He finds the need also to defend this process of deification: Which of your ancestors Established the area Of your beloved Country? (151) 
In so doing, Ocol rejects the possibility that his father is African. For no African or system of African origin defined the borders of modern Africa, borders which allow Ocol to call himself Ugandan. Those borders were, instead, established and legitimized by the European colonial presence, which Ocol, together with his agemates, has forced back to Europe. Thus it is in the deification of the European "father" that Ocol defines and establishes his own legitimacy. The African civilisation, which has been eulogistically defined by Lawino, does not, however, provide Ocol a psychological home, a place of comfort. As Ogunyemi claims, Ocol feels that "marrying Lawino was the result of a horrible dream" (28). Ocol shouts at her:

\section{Woman of Africa}

Whatever you call yourself,

Whatever the bush poets

Call you

You are not a wife! (134)

Some previous critics have found room in their interpretations to concur with Ocol's shout. Among them is Ruchoya, who states, "It [Song of Lawino] is, further, a statement full of quality and vigour characteristic of the traditional African motherhood ..." (55). While a minor element in Lawino's explicit statements, this traditional African motherly quality is, in Ruchoya's view, the primary motivation of Lawino's song. Similarly, La Magna claims: "Okot very appropriately used a woman as protagonist of this long lament as in Africa the role of the woman, and above all of mother, is greatly respected and thus, people are more likely to turn a sympathetic ear to her cry" (74). One finds that, despite the surface claims of the characters themselves to be, in fact, husband and wife, the text provides overwhelming clues to suggest a metaphorical interpretation. One also finds that, while Lawino unswervingly calls Ocol to safeguard the "pumpkin," Ocol is remains unyielding. In fact, he repudiates Lawino for holding on to traditions, customs and beliefs that not in sync with the modern times. One can, thus, proceed in this interpretive strategy, confident in the sound textual support for the view of Lawino and Ocol as a romanticised version of African culture and Ocol as a realistic representation of the continent today.

Every struggle for liberation is a struggle for cultural freedom. Thus, resistance to colonial/ neo-colonial domination is, in many ways, resistance to the culture of the coloniser. From the writings of literary artists to those of politicians, there has been a concerted effort in Africa to recover and promote cultures that were annihilated by colonialism or simply to find a cultural framework that is suitable to the African context. Writing about cultural nationalism in the aftermath of colonization, Abiola Irele notes that négritude appears as the culmination of the complete range of reactions provoked by the impact of western civilisation on the African, and of the whole complex of social and psychological factors that have gone to form black people's collective experience of western domination. Its roots lie far down in the total historical experience of the black man in contact with the white (Irele 322). The cultural nationalism exhibited by the négritude movement had two facets. On one hand, there was a negative gesture of refusal, a denial of an imposed world-order attributed to the white coloniser, and the wish for a cultural 'differentiation' which gave rise to a nascent political awareness, or a nationalist consciousness. On the other hand, there was a recasting of 
foreign and indigenous elements into a new cultural structure, which offered new possibilities of self-expression (Irele 323). The ideals of the négritude movement are relevant to this article because they provide a background to the cultural nationalism exhibited by Okot's poetry.

As it was during colonialism where Africans were drawn into the cultural world of the European but kept in a secondary position, in the neoliberal global order, Africans continue to occupy a secondary position in an economic system whose balancing scales are tipped in favour of the West. Cultural nationalism may be defined as the manifestation of the nationalist "sentiment" in cultural indices, which places emphasis on cultural symbols, ideas, beliefs and other artifacts and motifs shared by a group (Adedeji 432).

Boyd Shafer defines nationalism as a sentiment which unifies a group of people who have a real or imagined common historical experience and a common aspiration to live together as a separate and distinct people in the future (Shafer qtd. in Adedeji 432). Adedeji further argues that in the African context, cultural nationalism arises out of the unique cultural history of the people of Africa, the colonial onslaught on the continent and the conscious attempt by certain individuals or groups to seek ways and means of satisfying their nationalistic aspirations through a programme that resurrects the African past (Adedeji 432). Okot may not be advocating a return to an idyllic past, but his work bears out as a vicious attack on neo-imperialism in Africa.

Cultural nationalism tends to have specific objectives. Hutchinson (Ndlovu-Gatsheni 946) is of the view that 'cultural nationalism is a movement of moral regeneration which seeks to re-unite the different aspects of the nation - the traditional and modern, agriculture and industry, science and religion - by returning to the creative life-principle of the nation". Cultural nationalists therefore perceive of the nation as a product of history and culture and thus they seek to inspire 'love' of community, educating members of community on their common national heritage of splendour and suffering, engaging in naming rituals, celebrating cultural uniqueness, and rejecting foreign practices (Ndlovu-Gatsheni 947). While négritude as a cultural movement sought to resist colonialism and assert African values, Okot's cultural nationalism resists neo imperialism which manifests itself through unfair trade relations and the commercialisation of war in Africa.

In the first step towards the imagined and actual sovereignty of the nation both politicians and writers in Africa attempted to appropriate the past for their own present needs. This was necessary, because, as Frantz Fanon argued, "colonialism is not satisfied with snaring the people in its net or of draining the colonised brain of any form of substance. With a kind of perverted logic, it turns its attention to the past of the colonised people and distorts it, disfigures it, and destroys it" (149). Clearly many in Africa thought that this had happened, that English rule had deprived the Africans of their own history. Consequently, political and cultural nationalists, like Okot p'Bitek attempted to re-assert black pride, developing alternate interpretations of history, seeking to reclaim the past and counter the influence of English domination. For example, in Song of Lawino, Okot argues that African history should be read not as a series of failed rebellions against English rule over several centuries, but rather the opposite. He reshapes the narrative to one in which "Africa has won all along the line" because "no other people in the world has held so staunchly to its inner vision; none other has, with such fiery patience, repelled the hostility of circumstances, and in the end reshaped them after the desire of her heart” (1912, pp.45-6). In rewriting history to 
escape "the cliché version of the nationalist myth," Okot and other participants in the Negritude movement created a "more appealing myth," or myths, as each had a slightly different narrative but all rejected the imperial one (Garvin, 2005, p.116). In doing so they adhered to the concept that "freedom in the future is predicated on the liberation of the past" (Richards, 1991, p.121). They regained history from the pens of the coloniser. This involved not only returning to the source in literature and history, but also selecting those sources and ideals relevant to the present and future of the nation, making it "by and large... a modernising force" (Castle, 2011, p.293).

Okot p'Bitek's pragmatic acceptance of the inroads made by the English language in Africa, his emphasis on the interpenetration of the two linguistic traditions, his forward-looking views of poetry, and his relatively inclusive conception of the boundaries of African literature marked him out from many of his more polemic contemporaries. Literature in Africa transcends the narrow "battle of two civilisations" view of the revitalisation to embrace a pluralistic and aspirational vision of transnational literature and the centenary of revolutionary approaches provides an apt time for its recognition and reassessment.

Even in the primordial dismemberment of the original schema of things, Lawino apparently holds fast and furiously to her traditions. The contemporary arrangement of the African world has made treachery so glaringly permissible, yet cultural loyalists do not seem to recognise this dangerous trend. Okot appears to suggest, and largely so, that uncritical worship of cultural nationalism has blurred the vision of post-independence citizens. To surmount this visual blur, one has to carry themselves through this collective blindness to a higher place of being. In so doing, they rise to a new level of consciousness.

Superficially, Ocol's sentiments in Song of Ocol may seem like hubristic overreacting; yet they reveal pertinent issues about cultural nationalism in Africa. Although retracing cultural steps has significantly buttressed efforts towards the restoration of Africa's lost glory, there are indications that celebration and indeed worship of cultural value systems has blinded Africans to the political realities of the modern-day society. A mere return to Africa's cultural ancestry is not the solution to Africa's challenges. It is not enough to romanticise the past. Certain traditional practices are no longer sustainable. It is unrealistic to assume that the introduction of new ways of doing things is the reason Africans have challenges. Buck-passing is as escapist as it is delusionary. Africans must take practical steps to restore human dignity. The "diviner" must not be allowed to "plead with dread malaria" when a child's blood is "boiling with heavy malarial parasites raging through his veins" and all "pillars of fear [such as] witches, wizards, evil-eyes, sellers of fetish bundles, bones and claws and dealers in poisons [should be] put in a lake steamer, taken to the deepest part and cast into the void" (Ocol 130-132). At the end of the day, the colonised intellectual, as Fanon argues, has to realise that a national culture is not a historical reality waiting to be uncovered in a return to pre-colonial history and tradition, but is already existing in the present national reality. National struggle and national culture are inextricably intertwined in Fanonian analysis. To struggle for national liberation is to struggle for the terrain that allows for the growth of a culture and not "stupid village anthem of backwards ever, forwards never" (Ocol 132). Any claims to the contrary is retrogressive as it is bound to "cause misery and death" (Ocol 136). Africans can no longer remain "closed to progress" (Ocol 139). For true liberation to realised, Africa has to re-examine herself. A mere return to the past cannot resolve the complex issues bedeviling the 
continent. There are real issues that require practical solutions. They cannot be blamed on westernisation. To do so is escapist as it is insincere. Some of the issues that Africa is grappling with existed even before the colonialism. The postcolonial leadership has to be interrogated. The continent is "stuck in the stagnant mud of superstitions"; she is an "idle giant, basking in the sun, sleeping, snoring, twitching in dreams." It is "diseased with chronic illness, choking with black ignorance and chained to the rock of poverty" (Ocol 128). Yet Africans are unwilling to take practical initiatives, "always laughing and dancing [with] chains on [their] legs" (Ocol 128). Contemporary African leaders are copycats of former colonisers; they are "fat black capitalists in dark suits sipping the Scotch" (Ocol 152). These leaders do not seem to take pride in African cultural values. In spite of Africa's rich history, legendary voyages and great discoveries, streets and parks are named after foreigners. The future of the continent will be determined by decisions that Africans make today and there are only two options: confront the challenges or commit suicide. Ocol says:

You have only two alternatives

My sister,

Either you come in through the City Gate,

Or take the rope

And hang yourself (Ocol 152)

For Fanon, colonisers attempt to write the precolonial history of a colonised people as one of "barbarism, degradation, and bestiality" in order to justify the supremacy of Western civilisation. The condemnation of "glorifiers of the past" and Negritude scholars such as Aimé Césaire and Leopold Sengor may appear harsh and unjustified, but this combativeness is necessary for the foregrounding urgency and the need for practical approaches in dealing with challenges in contemporary African countries (Ocol 132). To upset the supremacy of the colonial society, writes Fanon, the colonised intellectual feels the need to return to their so-called "barbaric" culture, to prove its existence and its value in relation to the West. Fanon suggests colonised intellectuals often fall into the trap of trying to prove the existence of a common African or "Negro" culture. This is a dead end, according to Fanon, because it was originally the colonists who essentialised all peoples in Africa as "Negro," without considering distinct national cultures and histories. This points to what Fanon sees as one of the limitations of the Négritude movement. In articulating a continental identity, based on the colonial category of the "Negro," Fanon argues "the men who set out to embody it realised that every culture is first and foremost national."

An attempt among colonised intellectuals to "return" to the nation's precolonial culture is then, Fanon avers, ultimately an unfruitful pursuit as the "Old Homestead" is "all in ruins" (Ocol 127). Rather than a culture, the intellectual emphasises traditions, costumes, and clichés - "husks," "sacred trees" and "” ancestral shrines" which romanticise history in a similar way as the colonist would so that Africa has, metaphorically and ironically so, become "this rich granary of taboos, customs and traditions" (Ocol 129). The desire to reconsider the nation's pre-colonial history, even if it results in orientalised clichés, still marks an important turn according to Fanon, since by rejecting the normalised eurocentrism of colonial thought, these intellectuals provide a "radical condemnation" 
of the larger colonial enterprise. This radical condemnation attains its full meaning when we consider that the "final aim of colonisation," according to Fanon, "was to convince the indigenous population that it would save them from darkness." Okot's Song of Ocol does not entertain the persistent refusal among African cultural diehards to admonish national traditions in the face of colonial rule, according to Fanon, is a demonstration of nationhood, but one that holds on to a fixed idea of the nation as something of the past, a corpse.

A decisive turn in the development of the colonised intellectual is when they stop addressing the oppressor in their work and begin addressing their own people. This often produces what Fanon calls "combat literature," a writing that calls upon the people to undertake the struggle against the colonial oppressor. This change is reflected in all modes of artistic expression among the colonised nation and Okot's poems fall within this literary purview. Okot's poems, therefore, are attempts to delink Africans from the image imposed on them by coloniser. Whereas the common trope of postcolonial African literature is "an old Negro," Okot's poems present new artistic energy and dynamism that resists and undermines the common racist trope. For Okot, like Fanon, national culture is then intimately tied to the struggle for the nation itself, the act of living and engaging with the present reality that gives birth to the range of cultural productions. This might be best summarised in Fanon's idea of replacing the "concept" with the "muscle." Fanon is suggesting that the actual practice and exercise of decolonisation, rather than decolonisation as an academic pursuit, is what forms the basis of a national culture.

Like Fanon, Okot is careful to point out that building a national culture is not an end to itself, but a "stage" towards a larger international solidarity. The struggle for national culture induces a break from the inferior status that was imposed on the nation by the process of colonisation, which in turn produces a "national consciousness." This national consciousness, born of struggle undertaken by the people, represents the highest form of national culture, according to Fanon. Through this process, the liberated nation emerges as an equal player on the international stage, where an international consciousness can discover and advance a set of universalising values as suggested by the obliteration of "tribal boundaries" (Ocol 127). In the absence of this cultural vision, literary productions will always paint a pessimistic picture of Africa:

\section{What proud poem}

Can we write

For the vanquished? (Ocol 154)

\section{Conclusion}

This study demonstrates that Okot p'Bitek's poems, though largely perceived as espousing cultural nationalism, depart significantly from the militancy and escapist idealism of Sengorianism. Okot p'Bitek absolves fellow African poets of any blames. What they create is determined by the raw materials they gather from real-life experiences. It is important to note that Okot deliberately alludes to historical events and personalities in Africa to lend credence to his cultural propositions. He implicitly demonstrates his heavy leaning towards Fanonianism. His two poems and much of the contemporary postcolonial discussions on the role of the national culture in liberation struggles and decolonisation are, to a large extent, inspired by Fanon's postulations on culture. In particular, Fanon 
is partially credited for inspiring an interest about the way the individual human experience and cultural identity are produced in postcolonial writing. Fanon's theorising of national culture as first and foremost a struggle to overthrow colonial rule was a radical departure from other considerations of culture that took a more historical and ethnographic view.

Despite the fact that some theorists working in postcolonial studies have criticised Fanon's commitment to the nation as reflective of an essentialist and authoritarian tendency in his writing, his voice epitomises the reality in contemporary African countries and what must be done if new cultural quests have to be fulfilled. Christopher Miller also finds faults with Fanon for viewing the nation as the unquestioned site of anti-colonial resistance, since national borders were imposed on African citizens during the scramble for partition. Miller finds the lack of attention to the imposition and artificiality of national borders in Africa misleading as it overlooks the cultural and linguistic differences of each country that make theorising a unified national culture, as Fanon does, problematic. Particular or local histories are subordinate to the universal or global struggle of the nation.

Okot emphasises a sense of unified political consciousness onto the peasantry in their struggle to overthrow colonial systems of power. Peasant militancy in Fanon's analysis becomes the exact justification for his theory, yet does not necessarily exist in the material sense. He wrote that Fanon's dedication to a national consciousness can be read as a "deeply troubling" demand for cultural homogeneity and the collapse of difference. Bhabha, however, suggests Fanon's vision is one of strategy and any focus on the homogeneity of the nation should not be interpreted as "narrow-minded nationalism," but an attempt to break the imposed binaries of colonialism. This resonates with Fanon's argument that national cultural identity was basically a strategic step towards overcoming the assimilation of colonialism, and building an international consciousness where binaries of colonised and coloniser were dissolved.

"On National Culture" is also a notable reflection on Fanon's complex history with the Négritude movement. Aimé Césaire, Fanon's teacher and an important source of intellectual inspiration throughout his career, was the co-founder of the movement. While Okot's thinking in the two poems appears intersected with figures associated with Négritude, including a commitment to rid humanism of its racist elements and a general dedication to Pan-Africanism in various forms, it is critical of the idealist escapism, especially considering its historical context. Okot's poems initially appear to be inspired by the movement, which often revolved around the presumption that a unified African Negro culture existed. Négritude intended to enliven black culture with qualities indigenous to African history, but made no mention of a material struggle or a nationalist dimension. Meanwhile, throughout the essay, Fanon stressed the cultural differences between African nations and the particular struggles black populations were facing, which required material resistance on a national level. Those who call for black cultural unity yet they oppose Black nations' bids for independence from neocolonial tendencies.

\section{Works Cited}

Adedeji, J. Cultural Nationalism and the African Theatre. Africa: Africae Oriente. Vol. 40, no. 3, 1985, pp. 436-45. Adler, N. International Dimensions of Organizational Behavior. South-Western College Publishing, 1997. 
Anderson, B. Imagined Communities: Reflections on the Origin and Spread of Nationalism. Verso, 2006.

Anyumba, H. "Song of Lawino: A Creative Audacity." An Appreciation, vol. 35, no. 4, 2009, pp. 945-65.

Apoko, A. “At Home in the Village: Growing Up in Acholi.” East African Childhood: Three Versions. Ed. Lorene K. OUP, 1967, pp. 45-75.

Apte, M. 'Language in sociocultural context.' The Encyclopedia of Language and Linguistics, edited by R. E. Asher, Pergamon Press, 1994, pp. 2000-2010.

Fanon, F. The Wretched of the Earth. Translated from French by Richard Philcox, Grove Press, 2004.

Goodwin, K. "Pietry." The Writing of East and Central Africa. Ed. G. D. Killam, Heinemann, 1984, pp. 213-230. Irele, A. "Negritude or Black Nationalism." The Journal of Modern African Studies, vol. 3, no. 3, 1965, pp. 321-348.

Lustig, M., andand Koester, J. Intercultural Competence: Interpersonal Communication across Cultures. 3rd ed., Longman, 1999.

Miller, C. Theories of Africans: Francophone Literature and Anthropology in Africa. University of Chicago Press, 1990.

Ndlovu-Gatsheni, Sabelo J. "Making Sense of Cultural Nationalism and the Politics of Commemoration under the Third Chimurenga in Zimbabwe.” Journal of Southern African Studies, vol. 35, no. 4, 2009, pp. 945-65.

Hall, C. A Primer of Freudian Psychology. New American Library, 1979.

Heron, G. "Okot p'Bitek and the Elite in African Writing." Literary Half-Yearly 19.1 (1978): 66-93. The Poetry of Okot p'Bitek. Heinemann, 1976.

Heywood, A. "Modes of Freedom: The Songs of Okot p'Bitek." Journal of Commonwealth Literature, vol. 15, no.1, 1980, pp. 65-83.

Kamenju, G. "Black Aesthetics and Pan-African Emancipation." Umma, vol. 2, no.1, 1972, pp. 57-71.

La Magna, G. "Okot p’Bitek and the Search for Self-Identity." Quaderni di Lingue e Letterature 6, 1981, pp. 67-82. Lindfors, Bernth, ed. Mazungumzo (Interviews with East African Writers, Publishers, Editors and Scholars). Papers in International Studies: Africa Series 41. Athens, OH: Center for International Studies, Ohio U, 1980. "The Songs of Okot p'Bitek." The Writing of East and Central Africa. Ed. G. D. Killam. Heinemann, 1984, pp. 144-158. Obeichina, E. N. "Transition from Oral to Literary Tradition." Presence Africaine 63, 1967, pp. 140-161.

Okot p'Bitek. Song of Lawino and Song of Ocol. PEAK, 2011.

Ogundipe-Leslie, Molara. "The Female Writer and Her Commitment." Women in African Literature Today: A Review. Ed. Eldred Durosimi Jones. Trenton, NJ: Africa World P, 1987, pp. 5-13.

Ogunyemi, C. 0. "In Praise of Things Black: Langston Hughes and Okot p’Bitek." Contemporary Poetry 4.1 (1981): 19-39.

Ruchoya, M. N. "Lawino’s Complex Protest: A Socialist Reappraisal." Busara, vol. 3, no. 2, 1971, pp. 54-58.

Soyinka, Wole. The Man Died: Prison Notes of Wole Soyinka. Noonday, 1972 